\title{
A fogászati implantátumok csontbeépülését befolyásoló „klasszikus” tényezők változásai az elmúlt évtizedekben
}

\author{
Koppány Ferenc dr. - Bérczy Kinga dr. \\ Körmöczi Kinga dr. - Németh Zsolt dr. \\ Semmelweis Egyetem, Fogorvostudományi Kar, \\ Arc-, Állcsont-, Szájsebészeti és Fogászati Klinika, Budapest
}

\begin{abstract}
Szakmai körökben szinte mindenkinek természetes az, ami pár évtizede még elképzelhetetlennek tûnt: egy organikus környezetbe (csont) behelyezett anorganikus anyag (titán) integrálódik, és tartós pillére lehet a fogpótlásnak. Magát a csontintegrációt, amely az implantátum és a csont közötti szerkezeti és funkcionális kapcsolatot jelenti, a hatvanas évek végén fedezték fel és írták le. Ez jelenti a fogászati implantológia alapját. Ekkor fogalmazták meg azokat a feltételeket is, amelyek a csontintegráció pozitív vagy negatív lefolyását befolyásolják. Ezek a kérdések az alapkutatások részét képezik, éppen ezért a mindennapi klinikai gyakorlatban csak felszínesen kerülnek szóba. Az implantátum anyagi, formai jellemzői és felülete egyaránt hozzájárul a sikerességhez, amennyiben jól tervezünk és a megfelelő sebészi technikát alkalmazzuk. Célunk, hogy ismertessük az elmúlt évtizedekben végbement olyan változásokat, melyek az implantátumok egyre tökéletesebb integrációját és klinikai sikerességét eredményezték.

Orv Hetil. 2019; 160(37): 1455-1463.
\end{abstract}

Kulcsszavak: implantátumok, osseointegratio, felületkezelés

\section{Changes in the "classical" factors influencing dental implant-osseointegration in recent decades}

Nowadays, it is almost naturally taken among dentists that seemed unimaginable a few decades ago, namely that an inorganic material (titanium) inserted in an organic environment (bone) can be integrated and become a permanent pillar of prosthetics. Bone integration - meaning a structural and functional connection between the implant and the bone - itself was discovered and described in the late 1960s. This provides the basis of dental implantology. In those days, the conditions affecting the positive or negative course of bone integration have been formulated. This process is investigated at the level of basic research and rarely mentioned in the daily clinical practice. The material, form, and surface of the implant all contribute to success if we design well and apply the correct surgical technique. Our goal is to present the changes that have taken place over the past decades, which have resulted in an increasingly perfect integration and clinical success of implants.

Keywords: medical implants, osseointegration, surface treatment

Koppány F, Bérczy K, Körmöczi K, Németh Zs. [Changes in the "classical" factors influencing dental implant-osseointegration in recent decades]. Orv Hetil. 2019; 160(37): 1455-1463.

(Beérkezett: 2019. április 10.; elfogadva: 2019. május 3.) 


\section{Rövidítések}

$\mathrm{BIC}=($ bone-implant contact $)$ csont-implantátum érintkezés; $\mathrm{BL}=($ bone level $)$ csontszint $; \mathrm{BLT}=($ tapered bone level $)$ kúpos csontszint; $\mathrm{CBCT}=($ cone-beam $\mathrm{CT})$ kúpsugaras $\mathrm{CT} ; \mathrm{CP}=$ (commercially pure) kereskedelmi tisztaságú; $\mathrm{CT}=($ computed tomography) számítógépes tomográfia; EDI = $($ European Association of Dental Implantologists) Európai Implantológusok Szervezete GRADE $=$ (Grading of Recommendations Assessment, Development and Evaluation) Egészségügyi állapotfelmérési, ellátásfejlesztési és -értékelési ajánlások súlyozási rendszere; HA = hidroxiapatit; ITI = (International Team for Implantology) Nemzetközi Implantológiai Csoport; SLA = (sandblasting with large grit and acid etching) homokfúvás és savazás kombinált használata; $\mathrm{SPD}=$ (severe plastic deformation) súlyos képlékeny alakváltozás; $\mathrm{TCP}=($ tricalcium phosphate) trikalcium-foszfát; $\mathrm{TiO}_{2}=$ titán-oxid; $\mathrm{TL}=($ tissue level $)$ szöveti szint; UFSZ = ultrafinom szemcsés

A fogászati implantológia az egyike a legdinamikusabban fejlődő fogorvostudományi szakterületeknek. Számtalan publikációval, szakkönyvvel találkozunk nap mint nap, és folyamatosan növekszik a továbbképzések, kongresszusok száma, melyek ezzel a területtel foglalkoznak. Az 1960-as évek elején írta le Per Ingvar Brånemark (svéd ortopéd sebész) és Tomas Albrektsson az osseointegratiót, amely közvetlen szerkezeti és funkcionális kapcsolatot jelent a csont és az implantátum felszíne között. Eredményeikkel tudományos alapot teremtettek a biomedicina számos területén manapság nélkülözhetetlen protézisek és implantátumok számára. Ehhez kapcsolódóan fogalmazták meg a sikeres csontintegráció tényezőit. Az új ismeretek eredményei a medicina számos területén megmutatkoztak. A csípő teljes helyreállításának sebészetében megjelentek a cementezés nélküli protézisek, amelyek új sebészeti elveknek megfelelően kerültek behelyezésre. Ezeknél a csont és a protézis közötti teret nem tölti ki az implantátum rögzülését segítő cementréteg, hanem sajátos felszínnel rendelkeznek, amely a protézis csontintegrációjához vezet. Cementezett protézisek esetén a cement nem lép közvetlen kapcsolatba a csonttal, és nem ragasztóanyagként szolgál. Szerepe az, hogy a két felszín közötti egyenetlenségeket kitöltve a protézis erősebb rögzülését eredményezze. A használat során a cementből leváló részecskék azonban gyulladáshoz vezethetnek. A cementezés nélkül behelyezett korszerű csípőprotézisek megjelenése gyakorlatilag a modern fogászati implantátumok megjelenésével egyidejű. A csontintegráció feltételeinek megismerése kulcsfontosságú a sebészet területén. Az implantáció feltételeinek minél sikeresebb megvalósítása az eredmények javulásához vezet. Folyamatosan lépést kell tartani a csontintegrációt negatívan befolyásoló tényezőkkel $[1,2]$. Az elmúlt közel negyven esztendőben például megnövekedett a rizikóbetegségek előfordulásának gyakorisága. Idetartozik többek között a súlyos cukorbetegség, a csontritkulás szekunder formája, súlyos szív- és érrendszeri betegségek, kezelés alatt álló daganatos betegségek és fogászati szempontból a súlyos harapási rendellenességek. Idővel korszerúbb diagnosztikai eszközökkel és új mútéti ejárásokkal lettünk gazdagabbak, amelyek során újabb szövődmények is megjelentek $[3,4]$. Napjainkban komoly problémát jelent a biszfoszfonátkezelésen átesett (osteoporosis, csontáttétet adó daganatos megbetegedések, egyes reumatológiai kórképek miatt) betegek megbízható szájsebészeti, implantológiai ellátása. A biszfoszfonátok többféle módon is befolyásolják a csontújraképződés folyamatát: gátolják az osteoclastok múködését, illetve az érfalat károsító hatásuk van. Az állcsontokban - a kiemelkedően gyors anyagcsere miatt - különösen nagy mennyiségben halmozódnak fel ezek a gyógyszerek a többi csonthoz képest. Az állcsontokat érő sebészeti beavatkozások következtében előfordul, hogy a sebgyógyulás során kórokozó baktériumok gyulladást okoznak, és a sebgyógyulás, hámosodás nem következik be. Az osteoclastok múködésének gátlása révén az új csont képződésének folyamata nem lesz megfelelő, amit tovább ront az angiogenezist gátló hatás. Ennek eredményeképpen nyálkahártyafosztott, nekrotikus csontterület alakul ki, amely a legtöbb esetben csak radikális sebészi úton távolítható el, a beteg életminőségének jelentős romlását hagyva maga után [5].

\section{A fogászati implantátumokról}

Az elmúlt évtizedek tapasztalatai alapján elmondható, hogy megfelelő tervezés és kivitelezés mellett a múfoggyökér-beültetés megbízható megoldás a foghiányok kezelésében. A fogászati implantátumokra készített fogmúvek három fó részből állnak: az implantátumból, az ebbe csavarral rögzített protetikai fejből és az ezen rögzülő fogpótlásból. A rendszer közvetlen kapcsolatát a szervezettel maga az implantátum teste adja, amelyet általában furat képzését követően helyezünk az állcsontba. Az implantátum elsődleges mechanikai rögzülését hónapokig tartó gyógyulási folyamat követi, amelynek során az implantátum beépül, integrálódik a csontba. Ezt a folyamatot nevezzük osseointegratiónak. A csontintegrációt számos tényező befolyásolja, de az egyik legfontosabb az implantátum csonttal érintkező felületének kialakítása, mert valójában maga a felszín lép közvetlen kapcsolatba a szervezettel. Ezért van kiemelt szerepük a különböző felületkezelési eljárásoknak. A gyógyulási szakaszt követően (kb. 3 hónap) a beültetett implantátum integrálódik, a rágóerővel már terhelhető, így elkészülhet a fogpótlás. Ennek eredményeképpen a fogpótlás átvezeti a rágóerőt az implantátumokra, illetve az állcsontokra. Ebben az időszakban kezdenek érvényesülni a biomechanikai tényezők. A rágóerő nem megfelelő eloszlása az implantátum körül károsodást okozhat a környező szövetekben (lágyrészek, csont), amelyek felülfertőződve bakteriális gyulladást okozhatnak az implantátum körül (periimplantitis). A gyulladásos mediátorok hatására csontfelszívódás alakul ki, amely kezeletlen vagy kedvezőtlen esetben az implantátum elvesztésével járhat. 
A hosszú távon elhanyagolt szájhigiéné ugyanilyen eredményre vezethet, mert a fogpótláson felhalmozódó kórokozók az íny felől szintén a csontot elérő gyulladást okozhatnak. Fontos ezért a fogpótlás és az implantátum megfelelő széli záródása, amely csökkenti a kórokozók megtapadásának veszélyét. Ezek a jelenségek hasonlóan zajlanak le a szervezet egyéb területein használatos bioanyagok, implantátumok esetében. Teljes csípő-helyreállítás esetén is szükséges a megfelelő elsődleges stabilitás kialakítása, amelynek talaján létrejöhet a csontintegráció. A gyógyulási időszakban a csont és az implantátum felszíne között bekövetkező mozgások (mikromozgás) döntően befolyásolhatják a csontintegrációt. Amennyiben ezek az elmozdulások meghaladják a $150 \mu \mathrm{m}-\mathrm{t}$, úgy nagyobb valószínúséggel vándorolhatnak be kötőszöveti sejtek a két felszín közé. Ennek következtében a csont helyét a gyorsabban növekvő kötőszövet tölti ki, meggátolva az implantátum beépülését [6].

A csontintegrációval kapcsolatban a klinikusok érdeklődése a leginkább az új diagnosztikai módszerek és mútéti technikák felé irányul. Emellett az ortopéd sebészetben kifejezetten fontos a rehabilitáció kérdése. A beavatkozások általában erôsen megterhelik a szervezetet. Az egyik nemrég megjelent tanulmányban a beteg mütét előtti és mütét közbeni szuggesztióját végzik hangfelvételről a gyorsabb felépülés érdekében [7]. A sebészetben egyre nagyobb teret nyernek például a számítógép segítségével tervezett és végzett beavatkozások. Ennek egyik lehetősége az ún. irányított sebészet. Képalkotó eljárás - a leggyakrabban komputertomográfia - segítségével készítenek egy sebészi sablont, amely a CT-n számítógép segítségével megtervezett implantátumfuratok térbeli információit tartalmazza. Így - a fogpótlás szempontjából - elöre megtervezhető az implantátumok helye és mérete. A sablont a mütéti területre helyezve a CT-felvételnek megfelelően készülhetnek el az állcsontokban a furatok. Korábban a legelterjedtebb képalkotó eljárás a panorámaröntgen volt, és a nagy sugárterhelés miatt csak irányított sebészeti beavatkozás tervezésekor készült CT-felvétel. Az elmúlt 10-15 évben kifejlesztettek egy kis sugárdózisú komputertomográfiás eljárást, a cone-beam CT-t (CBCT). A CBCT alkalmas az állcsontok 3D-rekonstrukciós képalkotására. A módszer sajátosságaiból adódóan azonban csak a fej-nyak régióban terjedt el. Napjainkban egyre növekvő gyakorisággal használunk fel ilyen típusú felvételt nemcsak implantáció megtervezésekor, hanem egyéb fogászati diagnosztikai célból is. Ezen a területen szinte nap mint nap találkozunk változásokkal, újabb és jobb szoftverekkel. Hasonló a helyzet az implantációt megelőző preprotetikai csontpótló eljárásokkal vagy az alkalmazásukhoz szükséges anyagokkal is.

Az elmúlt évtizedekben jobban körvonalazódtak a csontintegrációt befolyásoló tényezők. Az 1980-as évek elején leírt, a csontintegrációt befolyásoló tényezők közül ötöt tartottak fontosnak [8]. Nem fontossági sorrendben a következőket: a) az implantátum anyaga,

b) az implantátum formája és mérete,

c) az implantátum beültetésének technikája,

d) az implantátum protetikai terhelésének időpontja és

e) az implantátum felülete.

Ezek a „klasszikusnak” számító tényezők azóta is folyamatosan a kutatások tárgyát képezik. Az elmúlt négy évtized után ismereteink bővülése mellett még mindig ezeket tartjuk az alapvető tényezőknek.

\section{Az implantátum anyaga}

Ahogy ezt az 1970-es évek végén Osborn leírta, a bioanyagokat három csoportra oszthatjuk [9]: a) biotoleráns anyagok, melyeket a szervezet rövidebb-hosszabb ideig elfogad, de idővel szöveti reakció alakul ki ellenük. Idetartoznak a múanyagok, az acélötvözetek, a króm-kobalt-molibdén ötvözetek (Vitallium); b) bioinert anyagok, melyek a szervezetbe biztonsággal beépíthetők, nem okoznak kóros szöveti reakciókat, és hosszú ideig szövetstabilak - ilyen például a titán is; c) bioaktív anyagok, melyek a sejteket, szöveteket proliferációra, differenciálódásra serkentik. A bioinert anyagok jellemző tulajdonsága, hogy mechanikai képességük jobb, mint a bioaktív anyagoké, de rosszabb, mint a biotoleránsoké, és fordítva érvényes ez a biológiai képességeikre is.

$\mathrm{Az}$ orális implantológiában leginkább alkalmazott anyag a titán és ötvözetei. A csípőprotézisek területén a leggyakrabban alkalmazott anyagok hasonlóan a titánalumínium-vanádium, valamint a kobalt-króm-molibdén ötvözetek. A titánnak jók a mechanikai tulajdonságai, illetve jellemző rá az alacsony fajsúly, a hővezető képesség, a könnyú megmunkálhatóság és a kiváló korrózióállóság. A mechanikai tulajdonságok közül kiemelkedik az, hogy rugalmassági állandója közelebb van a csontéhoz, mint a nemesacélnak és a kobalt-króm ötvözeteknek [10]. A felületén spontán kialakuló titán-oxid réteg biztosítja az anyag biokompatibilitását. A fogászati implantátumok alapja az esetek nagy részében Grade 2-es, Grade 4-es és Grade 5-ös minőségû tiszta titán (commercially pure, $\mathrm{CP}$ ); ezeket titántömbökből állítják elő, ipari forgácsolással. A 'Grade' jelölés a szennyezőanyagok százalékos tartalmáról ad információt. Grade 2 -es esetében például ez szén-, hidrogén, nitrogén-, vas- és oxigéntartalmat jelent, amely szám szerint maximum 0,03\% nitrogént, $0,3 \%$ vasat és $0,25 \%$ oxigént jelent. Szennyezőanyagok hozzáadásával a titán mechanikai tulajdonságai módosíthatók. A legkedveltebb alapanyag a Grade 4-es titán, de előszeretettel használnak még Grade 5-ös titánt is. A harmadik a listán a Grade 2-es titán. Grade 3-as titánt csak elvétve használnak, Grade 1-est meg kifejezetten ritkán. A különböző Grade-besorolású titánok tovább ötvözhetők. A titán ötvözeteit leginkább a viszonylagosan rosszabb korrózióállósságuk miatt elsősorban a protetikai elemek esetében alkalmazzák. Implantátum nem csak titánból készíthető. Az implantológia története során 
számos anyagot használtak (például különböző kerámiaés fémötvözeteket), azonban a legideálisabbnak eddig a titán mutatkozott. A cirkónium-dioxidból előállított implantátum az utóbbi évtized vívmánya. Ellenálló, magas hajlítószilárdságú és keménységű anyag. Kitûnő biokompatibilitása és ínyszéli zárása miatt csökkenti az implantátumok körül kialakuló gyulladás (periimplantitis) kialakulásának veszélyét. Az implantátumok körül kialakuló, hosszabb ideig fennálló kezeletlen gyulladás, ahogy korábban említettük, a környező csontszövet felszívódásához, illetve implantátumvesztéshez vezethet. A cirkóniumimplantátumok felhasználási területe az anyag fehér színe miatt elsősorban az esztétikai zónára, azaz a frontfogak területére esik, mert az íny szintjének csökkenése esetén sem a fémes szín túnik elő. Nagyon sok in vitro és in vivo vizsgálat támasztja alá, hogy a cirkóniumalapú implantátum a titánból készült implantátumok alternatívája lehet. A fent említett, kitűnő ínyszéli zárás, biokompatibilitás és a kiváló esztétikai hatás mellett negatívumként említik a cirkóniumimplantátumok esetleges törését is. Ebből kifolyólag alkalmazásuk a rágófogak területén kevésbé javasolt, mert ott az esztétikai szempontokat megelőzi a rágóerőből adódó teherviselés szempontja. A hosszú távú vizsgálatok hiánya is problémát jelent a cirkóniumalapú implantátumok elterjedésében [11]. Kevésbé elterjedt megoldás a két fém ötvözete (titán/cirkon). Ennek jeles képviselői a Straumann cég (Bázel, Svájc) Roxolid típusú implantátumai. Ezek az implantátumok halványszürke, homogén színűek, a titánhoz képest jobb mechanikai tulajdonsággal rendelkeznek. Ebből adódóan az általánosan használt átmérőhöz képest kisebb méretben is jó a teherbíró képességük, így keskenyebb csont esetén is lehetôvé válhat a beültetés csontpótlás elvégzése nélkül. A Roxolid implantátumok modern felületkezelési eljárásokkal kezelve kiváló osseointegratiós eredményeket mutatnak [12]. Vizsgálati és preklinikai stádiumban vannak az ún. ultrafinom szemcsés nanotitánok. Nanotitánt intenzív képlékeny alakítással (severe plastic deformation, SPD) vagy meleg profilhengereléssel lehet előállítani. A nagymértékű, nyíró alakváltozással járó állapotban az anyag nem reped, és kezdeti szemcseszerkezete ultrafinom szemcsésre (UFSZ), nanoszemcsésre transzformálódik. A nanotitánok magasabb folyáshatárral, nagyobb szilárdsággal és keménységgel rendelkeznek, és fokozottabb ellenállást mutatnak a korrózióval szemben (1. ábra).

\section{Az implantátum formája és mérete}

A fogászati implantátumok formája az elmúlt 40 évben nagyon sokat változott. Az ideális forma keresésében sokféle variáció jelent meg. Készült a csontba ültethető, penge alakú implantátum, a periosteum alá rögzített ún. subperiostealis implantátum és még számos más változat. Az elmúlt évek tapasztalatai alapján elmondhatjuk, hogy jelenleg egyértelműen a körszimmetrikus, a természetes foggyökerek elkeskenyedését követő, csavarme-

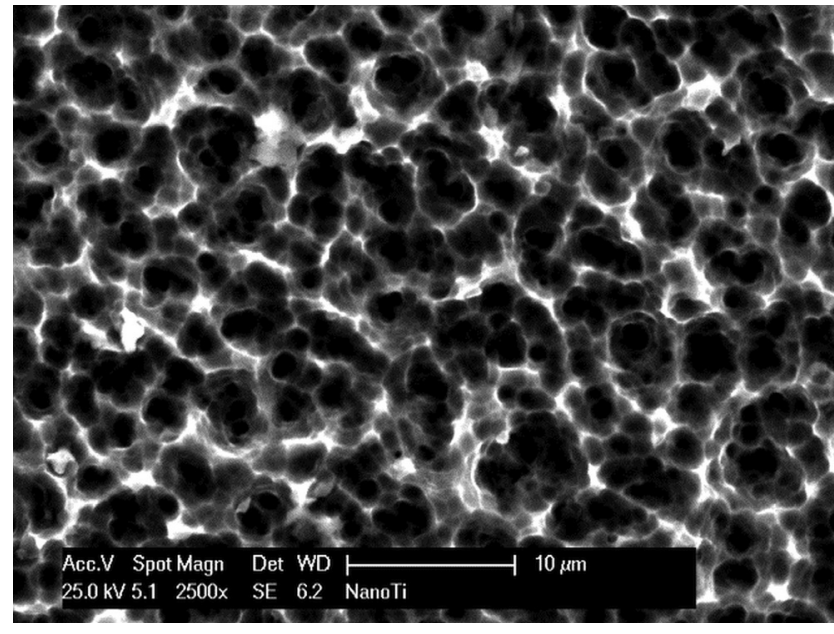

1/a ábra | Grade 2-es titán ultrafinom szemcsés szerkezetének (ún. nanoti tán) SEM-képe 2500-szoros nagyításban

SEM = pásztázó elektronmikroszkóp

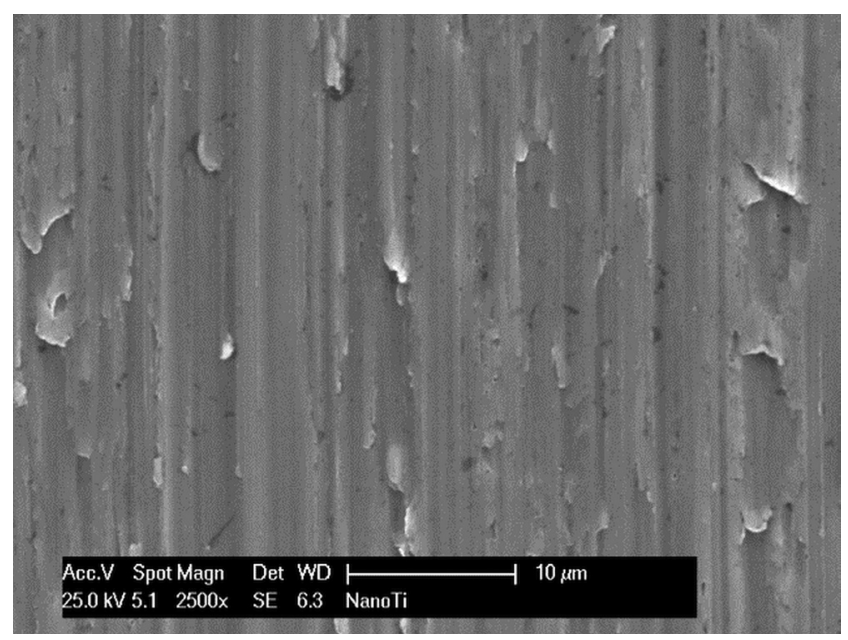

1/b ábra | Esztergált felszín; jól látható a nanotitán megnövelt felülete az esztergált felszínhez képest

nettel ellátott, kúpos forma a legideálisabb. Biomechanikai szempontból az implantátum formája alapvetően befolyásolja a terhelés alatt fellépő erők közvetítését a környező csontra. A formához tartozik a megfelelő nyaki rész kiképzése és a csavarmenetek kialakítása. Függetlenül attól, hogy milyen irányú erő éri az implantátumot, a legnagyobb erők a nyaki részen ébrednek. Fontos ezért a megfelelő sebészi technika. A formát illetően a nyaki részen kialakított, alacsony menetemelkedésü csavarmenet tovább csökkenti a feszültséget. Az implantátumok apicalis részén háromszög alakú éles menetek segítik a sebészi behelyezést. Koronális irányban haladva, csökkenő menetemelkedéssel és a menetek formájának trapezoid kialakításával pedig növelhető a csonttal közvetlenül érintkező felszín nagysága [13].

A standard méretú implantátumok mellett ma az ún. rövid és keskeny implantátumok használata a fogászati implantológia reflektorfényébe került. A műfoggyökér- 
beültetés alapvető feltétele a megfelelő minőségű és mennyiségű befogadó csont. Az esetek számottevő részében ez nem áll rendelkezésre, ezért csontpótló anyagok (esetleg autológ csont) behelyezésével segítjük eló új csont képződését. Ilyen beavatkozás gyakran történik a felső állcsontokon, ahol az arcüreg kiterjedése miatt szükség lehet ún. arcüregemelésre (sinus-lift). A beavatkozás során laterálisan képzett csontablakból megemeljük az arcüreg nyálkahártyáját, és csontpótló granulátumot helyezünk be, amely vázat képez az új csontsejtek számára, így biztosítva elegendő csontot a későbbi beültetéshez. Rövidebb, illetve kisebb átmérőjű, ún. keskeny implantátum használatával bizonyos esetekben elkerülhetjük a csontpótlást és a korábban említett sinus-liftet is. Használatukkal az anatómiai képletek védelme biztonságosabbá válik, a mütétek alacsonyabb morbiditásúak lesznek, a csontpótlás elkerülése miatt a költségek is jelentősen csökkennek [14].

A rövid implantátum fogalmának meghatározása folyamatosan változik, mert igaz, hogy használatukkal elkerüljük a csontpótlás következményeit, rövidebb implantátum behelyezésével azonban a csontintegráció folyamata és a biomechanikai tulajdonságok kedvezőtlenebbül alakulhatnak. Korábban megjelent publikációkban még a $\leq 10$ mm hosszúságú implantátumokat tekintették rövidnek. Az Európai Implantológusok Szervezetének (EDI) 2016-ban megrendezett konszenzuskonferenciája alapján ez az érték már csak $\leq 8 \mathrm{~mm}$, ugyanakkor meghatározták, hogy minimum 3,75 milliméteres átmérővel kell rendelkezniük az implantátumoknak (2. ábra). Az ultrarövid implantátum mint új fogalom került meghatározásra, amelynek hossza $\leq 6 \mathrm{~mm}$. A rövid implantátumoknak a standard implantátumokéhoz hasonlítható teherviselő képességét azzal magyarázzák, hogy új implan-

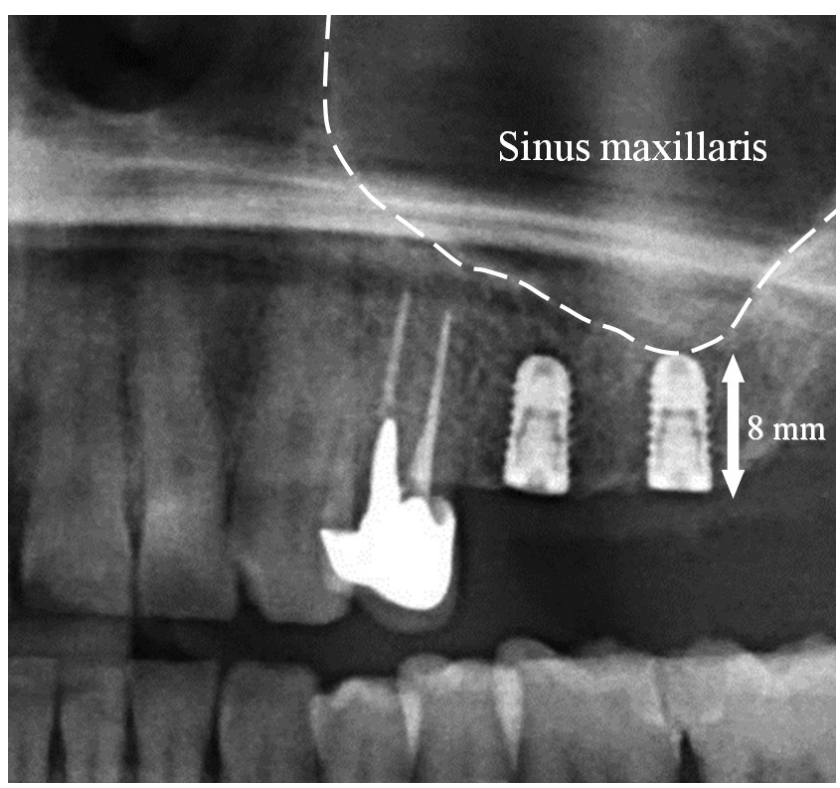

2. ábra

$8 \mathrm{~mm}$ hosszú bone level (BL-) implantátum röntgenképe. A rövid implantátum alkalmazásával elkerülhető az arcüreg emelésének mütétje (sinus-lift) tátumformával (tapered bone level, BLT), cirkóniumtitán ötvözettel (Roxolid) és SLActive felszínnel rendelkeznek.

Ugyanakkor elmondhatjuk, hogy bár az irodalom alapján a rövid implantátumok megbízhatóan és biztonságosan használhatók, jelenleg nem rendelkezünk evidence-based eredményekkel, hanem csak rövid távú, empirikus tapasztalatokkal [15].

Hasonló a helyzet az ún. keskeny implantátumok esetében. A 2016-ban megrendezett EDI-konszenzuskonferencia óta minden olyan implantátumot, amelynek átmérője kisebb, mint $3,5 \mathrm{~mm}$, keskenynek nevezünk, a 2,7 mm-nél keskenyebbet pedig miniimplantátumnak. A keskeny implantátumok alkalmazásáról is kevés hosszú távú tapasztalat áll rendelkezésünkre [16]. Éppen ezért az ismert és olvasott adatokat óvatosan kell kezelnünk.

\section{Az implantátum beültetésének technikája}

Talán ez az a terület, amelyen a legtöbb változtatás ment végbe az elmúlt évtizedekben. Nem is vállalkozhatunk mindnek az ismertetésére, de két fontos témát kiemelnénk. Az egyik az implantátum nyaki részének kiképzéséből adódó kérdések. A fogászati implantátumokat korábban szinte kizárólag polírozott nyaki peremmel készítették. Ez a rész nem volt a csontba süllyesztve, hanem a környező lágyrészekkel érintkezett, mintegy gallérként kialakítva. Ezeket nevezték később a lágyrész szintjében végződő, ún. szöveti szintű (tissue level, TL) implantátumoknak. Az ezredfordulót követően megjelentek a polírozott nyak nélküli, teljes hosszábban felületkezelt és a csont szintjében végződő implantátumok (bone level, BL). A problémakör lényegében a kétféle implantátum nyaki részét érintő gyógyulási, lágyrészesztétikai és biomechanikai különbözőségek kérdéseit és az indikációs területeket ölelte fel (3. ábra). 2010-ben, Genfben a Nemzetközi Implantológiai Csoport (ITI) nemzetközi kongresszusán külön szekciót szántak annak a kérdésnek a tisztázására, hogy milyen esetben indokolt TL- vagy BL-implantátumokat behelyezni. Neves szakemberek fogalmazták meg a BL-implantátumok indikációs területét [17]. Érdekes lehet az is, hogy a BL-implantátumot milyen mélységben helyezzük be a csont szintjéhez képest. Az irodalom eltérő eredményeket ír le esetenként attól függően, hogy supra-, epi- vagy subcrestalisan helyezzük be az implantátumot, azaz hogy az implantátum felső pereme az állcsont szintje fölött, vele egy szintben vagy kismértékben alatta végződik-e. Nincs egyértelmű válasz. Egyes szerzők azt mondják, hogy nincs szignifikáns különbség, hogy sub- vagy epicrestalisan rakjuk be az implantátumot, ugyanakkor van, aki a supracrestalis behelyezést javasolja [18, 19].

A másik érdekes kérdés, hogy a sebészi fúrón kívül használjunk-e piezoelektromos eszközt a furat kialakításához vagy sem. A piezokészülék használata rutinos, jó sebész kezében kincs lehet, mert nem sérti a környező, fontos lágyrész-képleteket (például a nervus alveolaris 
a)

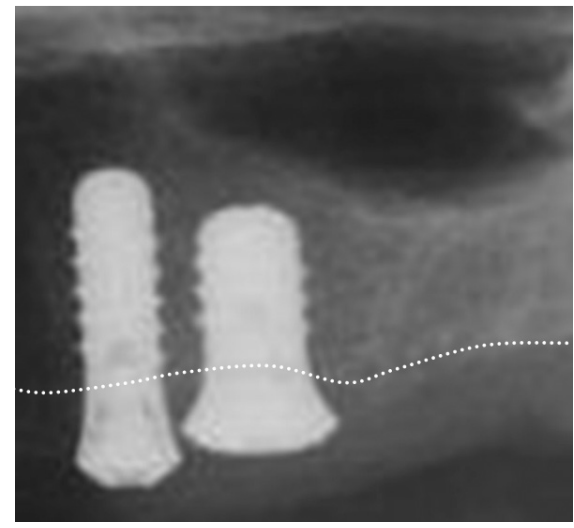

b)

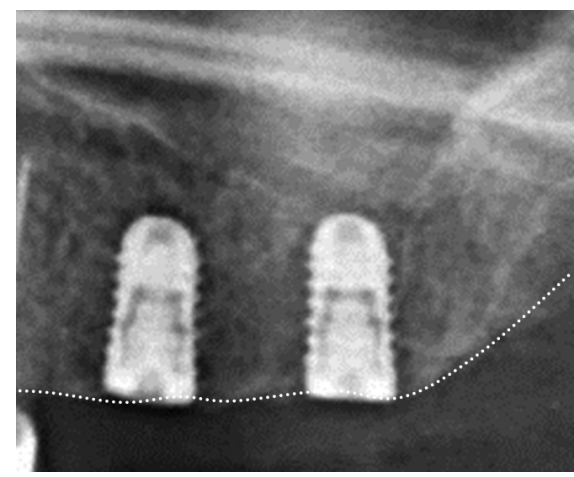

c)

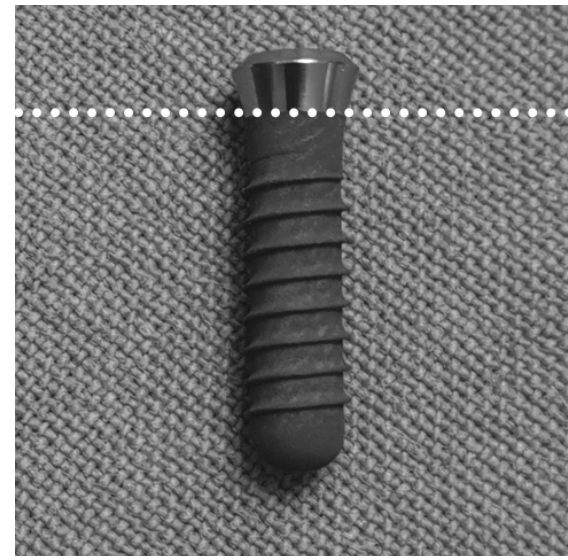

d)

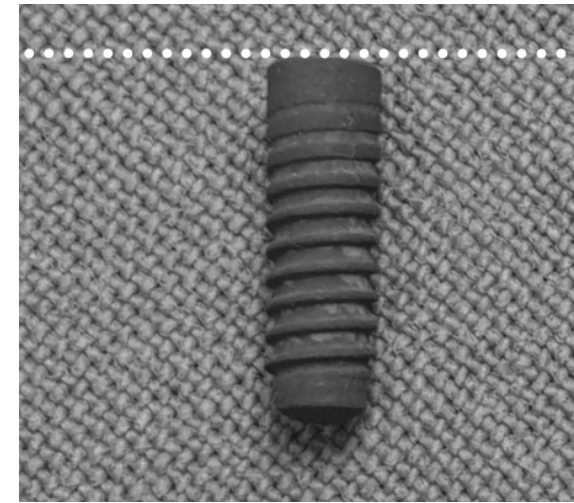

3. ábra inferior a mandibulában, illetve az arcüreg-nyálkahártya a felső állcsont esetén), egyenesen, pontosan lehet vele preparálni. Megkíméli a lágyszöveteket; idegszövet vagy a Schneider-membrán esetén ez komoly szövődmények elkerülését jelentheti. Ugyanakkor azt is tudjuk, hogy használata gyakorlatot és türelmet igényel. Ha nagy eróvel nyomjuk, akkor a csont túlmelegedhet, és emiatt akár nekrotizálhat is. A cementezés nélkül kialakított csípőprotézisek esetében az egyik legnagyobb kérdéskört szintén az ideális sebészi technikával párosult ideális forma megtalálása jelenti $[20,21]$.

\section{Az implantátum protetikai terhelésének időpontja}

A Nemzetközi Implantológiai Csoport (ITI) ötödik konszenzuskonferenciáján egyértelmúen leírják a lehetséges terhelési protokollokat. Ezek alapján azonnali fogpótlásról akkor beszélhetünk, amikor a fogpótlás az implantátum behelyezését követő 48 órán belül elkészül, de nincs okklúzióban, azaz a fogsor záródásakor nem érintkezik a szemközti fogakkal. Azonnali a terhelés, amikor a fogpótlás az implantáció után 48 órán belül felhelyezésre és okklúzióba kerül. Korai a terhelés, amikor a fogpótlás 48 óra után, de 3 hónapon belül okklúzióba helyezve készül el. Késleltetett a terhelés, ha a fogpótlás a végleges formájában a hagyományos gyógyulási idő (3-6 hónap) után készül el [22]. Természetesen más a protokoll a szóló implantátumok esetében részleges fogatlanság mellett, mint a kiterjedt foghiány esetén. A rendszeresen megtartott konferenciák (2004, 2009, 2014) konszenzusai mindig újabb és újabb módósításokat hoznak, érdemes tehát óket figyelemmel kísérni [23, 24].

\section{Az implantátum felülete}

A felület változásainak pontos biológiai értéke nehezen ítélhetô meg, de az biztos, hogy befolyásolja a szöveti gyógyulást, a sikerességet, az osteoblastproliferációt a sejtek fenotípusának megváltoztatásával, azoknak a differenciálódását és a hormonok hatására a csontsejtválaszt is. A felület mechanikai egyenetlenségei fontos szerepet játszanak a csontsejtekkel való kapcsolatban. Ma már tényként tartják számon, és számos szerző bizonyította, hogy az érdesített felület a csontintegráció szempontjából jobb, mint a sima felületi kiképzés.

Az implantológiai kutatások során nyitott kérdés maradt, hogy milyen az ideális felületi morfológia, mekkora felületi elemek, milyen formájú struktúrák és ezeknek milyen térbeli elhelyezkedése szükséges a tökéletes csontintegrációhoz. A felület morfológiája az érdességének a háromdimenziós megjelenítését jelenti.

Az irodalomban több mint száz olyan paramétert, mérési jellemző́t írtak már le, amellyel az egyes felületeket és az azokon lévő felületi elemeket számszerúen is jellemezhetjük. Jellemezni lehet a felszín minőségét az ún. 
BIC- (bone-implant contact) értékkel is, amely azt mutatja meg, hogy az implantátum felületének hány százaléka érintkezik közvetlenül a csonttal.

A legújabb kutatások azonban a mikrogeometria jelentőségét nem a felületnövelésben, hanem a csontképzésre gyakorolt hatásban látják. A létrejövő érdesség a szövetkultúrákból származó megfigyelések szerint gyorsítja a csontsejteknek a felületre történő migrációját. A kutatási eredmények alapján valószínúnek látszik, hogy bizonyos felületi mikrogeometriák olyan sejtfenotípusokat hoznak létre, amelyek könnyebben alakulnak át osteoblastokká [25-27].

Az évtizedek során számos felületkezelési eljárást fejlesztettek ki. Ezek közül csak azokat említjük meg, amelyek a mai, korszerü morfológiai elemek kialakítását teszik lehetővé.

\section{Esztergálás}

A plazmaszórással együtt a klasszikus felületkezelési eljárásokhoz tartozik. Az implantátum felületét esztergagép munkálja meg. Az esztergált felszínt nagyon gyakran referenciamintaként alkalmazzák az összehasonlító kísérletekben. Az esztergált felszínről szóló irodalmi beszámolók mindig erős, masszív csontképződést írnak le az implantátum körül, amely stabil implantátum-csontszövet kapcsolatot eredményez.

\section{Bevonás bioaktív anyaggal}

Az implantátum felszínére hidroxiapatit (HA) kerámiát vagy trikalcium-foszfát (TCP) kerámiát visznek fel, átlagosan 30-70 mikrométer vastagságban. Az 1980-as évektől kezdődően egyre gyakrabban alkalmazták ezt a módszert, és azóta megjelentek azok a problémák, amelyek a mai napig nem megoldottak. A problémák egy része technológiai jellegú, amelyek abból adódnak, hogy a fém és a kerámia hőtágulási és rugalmassági együtthatója eltér egymástól, ezért nem megfelelő terhelés esetén az implantátumról leválhatnak a hidroxiapatit szemcsék. Felmerült az a kérdés is, hogy a tapadás a fém felületén milyen terhelést visel el, és ez az idő folyamán hogyan változik, valamint az sem tisztázott, hogy a technológiai eljárás nem változtatja-e meg a fém felületének mechanikai tulajdonságait.

A bioaktív anyaggal történő bevonással az a fó probléma, hogy a kecsegtető rövid távú sikerek ellenére a hoszszú távú eredmények nem kedvezőek. Ennek ellenére manapság is próbálkoznak nanoméretü bioaktív anyagok felvitelével $[28,29]$.

\section{Titán-oxiddal történó érdesités}

A titán-oxiddal történő érdesítés azon alapul, hogy a titán felületén spontán kialakult titán-oxid réteget mesterségesen „felduzzasztják”. A módszer abban különbözik az anódos oxidációtól, hogy itt a folyamatot nem követi hőkezelés. A hőkezelés elmaradása miatt a porózus szerkezetű titán-oxid nem alakul ki, hanem a felület kikristályosodik [30].

\section{Lézeres felületkezelés}

Lézeres felületkezelések esetében neodímium-üveg lézert alkalmaznak, ahol a kibocsátott lézersugár hullámhossza $1054 \mathrm{~nm}$, energiája 0-3 J/impulzus, és a sugár által „kezelt” felszín nagysága 2 négyzetmilliméter. A felszíni hőmérséklet elérheti az 5000-6000 ${ }^{\circ} \mathrm{C}$-t is, amely a besugárzás időtartamának végéig 50-100 mikron mélységü, olvadt felületi réteget hoz létre. A kezelés vákuumban vagy célszerúen választott gázatmoszférában történik. A besugárzás végeztével az olvadt anyagréteg az implantátum érintetlen, hideg tömegének hatására néhány nanoszekundum alatt ismét megszilárdul, és morfológiájában megőrzi az olvadt állapot utolsó pillanatában jelen lévő felületi alakzatokat. A lézerek másik lehetséges fajtái az ún. excimerlézerek, amelyek a nem termikus lézerek csoportjába tartoznak, azaz alkalmazásuk nem hőhatáson alapul, hanem mechanikai behatásokat okoznak [31].

\section{Homokfúvás és savazás kombinált használata (sandblasting with large grit and acid etching, SLA)}

A kombinált módszerek közül a legismertebb eljárásokhoz tartozik az SLA-felszín, amikor két metódust ötvöznek azok előnyös tulajdonságainak kihasználására. Említésre méltó módszer azért is, mert ez az egyetlen olyan kombinált eljárás, melyet iparilag előallított, humán implantátumok felületén is alkalmaznak. Az irodalomban és a kereskedelemben is a leginkább elfogadott felületi struktúra (4. ábra) [32].

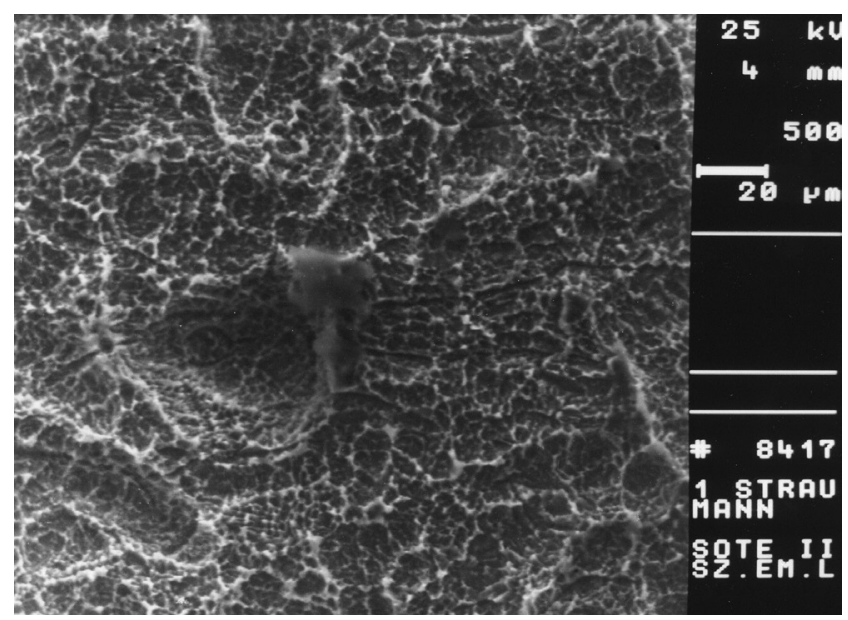

\begin{tabular}{l|l} 
4. ábra & $\begin{array}{l}\text { SLA-felszín SEM-képe 2000-szeres nagyításban } \\
\text { SEM = pásztázó elektronmikroszkóp; SLA = homokfúvás és sa- } \\
\text { vazás kombinált használata }\end{array}$
\end{tabular} 


\section{Nanocsöves felületek}

20 éve írták le először a sokatomos szénmolekulák (fullerének) nanocsöves elrendeződését. A fullerének legalább hatvan atomból állnak, szabályos zárt szerkezetet képeznek, és ezáltal sajátos anyagtani tulajdonságokat nyernek. Amennyiben a zárt szerkezet csöves elrendeződést nyer (nanocső), úgy a csövecskék térbeli elrendeződésének megváltoztatása a fullerént tartalmazó anyag tulajdonságainak megváltoztatását teszi lehetővé. Sajátos elektrokémiai tulajdonsága, nagy felületi energiája, valamint szilárdsága miatt számos ipari felhasználásra ad lehetőséget. A nanocsöves elrendezés nemcsak szénmolekulákkal, hanem más anyagokkal is létrehozható. Biológiai szempontból a legnagyobb jelentősége a titánoxidból $\left(\mathrm{TiO}_{2}\right)$ kialakított nanocsöves szerkezetnek van. Ezeknek a legelterjedtebb kialakítása úgy történik, hogy egy sima, elektropolírozott felszínre nanocsöveket visznek fel anodizációs eljárással. Ez a felépítés sajátos elektromos, kémiai és biológiai hatásokat eredményez, amelyek a csövecskék elrendezésével megváltoztathatók, hangolhatók $[33,34]$.

\section{Következtetés}

Az alapkutatási témák általában nem népszerúek a kongresszusokon, továbbképzéseken, ugyanakkor a klinikai vizsgálatokhoz szervesen kapcsolódnak. Klinikai következtetést levonni általában csak hosszú távú tapasztalatok alapján lehet. Ez az implantológiában vagy akár a csípő-helyreállításban legalább tíz évet jelent. Éppen ezért egy-egy újítás elterjedése és meghonosodása a mindennapi gyakorlatban lassú folyamat. Az első csavarimplantátumok felületének kialakítása közel húsz évig, kizárólag esztergálással történt. A titán-oxid felület részletesebb megismerése és új technológiai folyamatok alkalmazása később elősegítette összetettebb, jobban integrálódó felszín létrehozását. Az elmúlt évtizedek elegendő időt biztosítottak arra, hogy a csontintegráció „klasszikus” feltételei maradandó érvényt szerezzenek maguknak. A kutatások leírása egyre inkább halad a jól követhető és összehasonlítható eredmények irányába, ami elősegíti az implantológia tételeinek tapasztalatokon alapuló megfogalmazását. A technika fejlődése mellett hosszú távú klinikai tapasztalatokkal rendelkezünk, és az alapkutatások eredményei a gyakorlatban is megmutatkoznak. Napjainkban az implantátumokra készülő fogpótlások kiszámítható megoldást jelentenek. Mind a fogászati implantátumok, mind a csípőprotézisek tekintetében ez kb. 60-80\%-os csont-implantátum kapcsolatot jelent. A fennmaradó részt általában kötőszövet teszi ki. Szükség van azonban az osseointegratio körülményeinek javítására. Ennek egyik fó oka az, hogy növekszik a csontot érintő megbetegedések száma (osteoporosis, biszfoszfonátok) és az implantátumokat érintő bakteriális gyulladásos esetek (periimplantitis) száma. A kutatások és klinikai tapasztalatok alapján a legnagyobb változás az implantátumok felszínének további módosításától várható. Ezek a tanulmányok jelenleg előtérben vannak, és jellemző rájuk, hogy egyre inkább haladunk a nanotartomány felé. A felületi érdességek mintegy kémiai katalizátorként is múködnek, és közvetlenül hatnak a sejtekre. Mindezen eljárások javítják a csontintegrációt, azonban a nem megfelelő protetikai tervezés és sebészi technika továbbra is egyértelmú sikertelenséghez vezet. Amennyiben a tervezés és a sebészi kivitelezés megfelelő, úgy jobban érvényre juthatnak az alapkutatások eredményein alapuló tényezők.

Anyagi támogatás: A közlemény megírása, illetve a kapcsolódó kutatómunka anyagi támogatásban nem részesült.

Szerzői munkamegosztás: K. F.: Leíró felületmorfológia. B. K.: Az implantátumok alakja és formája. K. K.: A protetikai terhelés. N. Zs: A sebészi technika. A végleges változatot valamennyi szerző elolvasta és jóváhagyta.

Érdekeltségek: A szerzőknek nincsenek érdekeltségeik.

\section{Irodalom}

[1] Harris WH. Long-term results of cemented femoral stems with roughened precoated surfaces. Clin Orthop Relat Res. 1998; 355: 137-143.

[2] Albrektsson TA, Johansson CJ. Osteoinduction, osteoconduction and osseointegration. Eur Spine J. 2001; 10(Suppl 2): S96S101.

[3] Joób-Fancsaly Á, Kerekes F, Koppány F, et al. Changes in the indications for oral surgical implants based on statistical analysis. [Az implantációs sebészeti beavatkozások indikációs területének változása a statisztikai vizsgálatok tükrében.] Fogorv Szle. 2007; 100: 103-107. [Hungarian]

[4] Schreindorfer K, Kiss Á, Marada G. Maxillary sinusitis as a diagnostical adverse finding of the dental cone-beam computed tomography study. [Sinusitis maxillaris mint a fogászati cone-beam komputertomográfiás vizsgálat melléklelete.] Orv Hetil. 2017; 158: 1747-1753. [Hungarian]

[5] Zurányi A, Vasziné Szabó E, Tóth Z. Risk assessment of medication-related osteonecrosis of the jaw in general dental practice. [A gyógyszer által indukált állcsontnecrosis-kockázat mértékének meghatározása az általános fogorvosi gyakorlatban.] Orv Hetil. 2019; 160: 243-251. [Hungarian]

[6] Pancanti A, Bernakiewicz M, Viceconti M. The primary stability of a cementless stem varies between subjects as much as between activities. J Biomech. 2003; 36: 777-785.

[7] Szeverényi C, Csernátony Z, Balogh Á, et al. Effects of therapeutic suggestions on the recovery of patients undergoing major orthopaedic surgery. [Az ortopédiai nagymútétek során alkalmazott terápiás szuggesztiók hatása a beteg gyógyulására.] Orv Hetil. 2018; 159: 2011-2020. [Hungarian]

[8] Albrektsson T, Brånemark PI, Hansson HA, et al. Osseointe grated titanium implants. Requirements for ensuring a longlasting, direct bone-to-implant anchorage in man. Acta Orthop Scand. 1981; 52: 155-170.

[9] Osborn JF. Biomaterials and their application to implantation. SSO Schweiz Monatsschr Zahnheilkd. 1979; 89: 1138-1139.

[10] Bourne RB, Rorabeck CH, Burkart BC, et al. Ingrowth surfaces. Plasma spray coating to titanium alloy hip replacements. Clin Orthop Relat Res. 1994; 298: 37-46. 
[11] Sivaraman K, Chopra A, Narayan AI, et al. Is zirconia a viable alternative to titanium for oral implant? A critical review. J Prosthodont Res. 2018; 62: 121-133.

[12] Altuna P, Lucas-Taulé E, Gargallo-Albiol J, et al. Clinical evidence on titanium-zirconium dental implants: a systematic review and meta-analysis. Int J Oral Maxillofac Surg. 2016; 45: 842-850.

[13] Lan TH, Du JK, Pan CY, et al. Biomechanical analysis of alveolar bone stress around implants with different thread designs and pitches in the mandibular molar area. Clin Oral Investig. 2012; 16: 363-269.

[14] Thoma DS, Zeltner M, Hüsler J, et al. EAO Supplement Working Group 4 - EAO CC 2015 Short implants versus sinus lifting with longer implants to restore the posterior maxilla: a systematic review. Clin Oral Implants Res. 2015; 26(Suppl 11): 154169.

[15] Bérczy K, László Zs, Göndöcs Gy, et al. Changes of trends in the size of the dental implants in recent years. Part 1 . The role of short implants in dental implantology. The literature review. $[\mathrm{Az}$ implantátumok méretváltozásának tendenciái az utóbbi években. 1. rész. Rövid implantátumok szerepe a fogászati implantológiában. Irodalmi áttekintés.] Fogorv Szle. 2016; 109: 136140. [Hungarian]

[16] Guidelines of the 11th European Consensus Conference 2016. Short, angulated and diameter-reduced implants. EDI J. 2016; 12(1): 16-19.

[17] Buser D, Schmid B, Belser UC, et al. The new bone level implants - clinical rationale for the development and current indications for daily practice. Int Dent SA. 2010; 12: 58.

[18] Gualini F, Salina S, Rigotti F, et al. Subcrestal placement of dental implants with an internal conical connection of $0.5 \mathrm{~mm}$ versus $1.5 \mathrm{~mm}$ : outcome of a multicentre randomised controlled trial 1 year after loading. Eur J Oral Implantol. 2017; 10: 73-82.

[19] Rocío AG, Amparo AP, Peñarrocha-Oltra D, et al. Marginal bone loss in relation to platform switching implant insertion depth: an update. J Clin Exp Dent. 2012; 4: el73-e179.

[20] Barrak I, Joób-Fancsaly A, Varga E, et al. Effect of the combination of low-speed drilling and cooled irrigation fluid on intraosseous heat generation during guided surgical implant site preparation: an in vitro study. Implant Dent. 2017; 26: 541-546.

[21] Gurdán Zs, Vajta L, Tóth Á, et al. Effect of pre-drilling on intraosseous temperature during self-drilling mini-implant placement in a porcine mandible model. J Oral Sci. 2017; 59: 47-53.

[22] Gallucci GO, Benic GI, Eckert SE, et al. Consensus statements and clinical recommendations for implant loading protocols. Int J Oral Maxillofac Implants 2014; 29(Suppl): 287-290.

[23] Cochran DL, Morton D, Weber HP. Consensus statements and recommended clinical procedures regarding loading protocols for endosseous dental implants. Int J Oral Maxillofac Implants 2004; 19(Suppl) 109-113.

[24] Weber HP, Morton D, Gallucci GO, et al. Consensus statements and recommended clinical procedures regarding loading protocols. Int J Oral Maxillofac Implants 2009; 24(Suppl) 180-183.

[25] Joób-Fancsaly Á, Divinyi T, Huszár T, et al. New quantitative method to evaluate the effect of the surface morphology of dental implants on osseointegration on clinical cases. [A fogászati implantátumok felületkezelésének csontintegrációra kifejtett hatásának új, kvantitatív mérési lehetőségei klinikai esetek kapcsán.] Fogorv Szle. 2014; 107: 59-66. [Hungarian]

[26] Kiss G, Sebók B, Szabó PJ, et al. Surface analytical studies of maxillofacial implants: influence of the pre-operational treatment and the human body on the surface properties of retrieved implants. J Craniofac Surg. 2014; 25: 1062-1067.

[27] Nagy P, Joób-Fancsaly Á, Schindler Á, et al. Surface modification of dental implants. [Fogászati implantátumok felületkezelése.] Biomech Hung. 2014; 7: 42-49. [Hungarian]

[28] Sebők B, Kiss G, Szabó PJ, et al. SEM and EDS investigation of a pyrolytic carbon covered $\mathrm{C} / \mathrm{C}$ composite maxillofacial implant retrieved from the human body after 8 years. J Mater Sci Mater Med. 2013; 24: 821-828.

[29] Sebők B, Kiss G, Szabó PJ, et al. Carbon/carbon implants in oral and maxillofacial surgery - Part 2. [Karbon/karbon implantátumok az arc- és állcsontsebészetben - 2. rész.] Orv Hetil. 2012; 153: 744-750. [Hungarian]

[30] Degidi M, Nardi D, Piattelli A. 10 year follow-up immediately loaded implants with TiUnit porous anodized surface. Clin Implant Dent Relat Res. 2012; 14: 828-838.

[31] Joób-Fancsaly Á, Divinyi T, Karacs A, et al. Survival and success rate of dental implants treated with high intensity laser. [Lézerrel felületkezelt dentális implantátumok túlélési és sikerességi rátájának vizsgálata.] Fogorv Szle. 2015; 108: 75-80. [Hungarian]

[32] Schwarz F, Herten M, Sager M, et al. Bone regeneration in dehiscence-type defects at chemically modified (SLActive ${ }^{\circledR}$ ) and conventional SLA titanium implants: a pilot study in dogs. J Clin Periodontol. 2007; 34: 78-86.

[33] Weszl M, Tóth KL, Kientzl I, et al. Investigation of the mechanical and chemical characteristics of nanotubular and nano-pitted anodic films on grade 2 titanium dental implant materials. Mater Sci Eng C Mater Biol Appl. 2017; 78: 69-78.

[34] Joób-Fancsaly Á, Karacs A, Pető G, et al. Effects of a nano-structured surface layer on titanium implants for osteoblast proliferation activity. Acta Polytech Hung. 2016; 13: 7-25.

(Koppány Ferenc dr., Budapest, Mária u. 52., 1085 e-mail: koppany.ferenc@dent.semmelweis-univ.hu)

A cikk a Creative Commons Attribution 4.0 International License (https://creativecommons.org/licenses/by/4.0/) feltételei szerint publikált Open Access közlemény, melynek szellemében a cikk bármilyen médiumban szabadon felhasználható, megosztható és újraközölhetö, feltéve, hogy az eredeti szerző és a közlés helye, illetve a CC License linkje és az esetlegesen végrehajtott módosítások feltüntetésre kerülnek. (SID_1) 